\title{
Gastroprotective Effect of Ethanol Stem Bark Extract of Pepolo (Bischofia javanica Blume) Against Aspirin-Induced in Wistar Rat
}

\author{
Yuliet Susanto*, Rini Saputri', Khildah Khaerati ${ }^{1}$ \\ ${ }^{1}$ Department of Pharmacy, Faculty of Mathematics and Natural Sciences, Tadulako University, \\ Palu, Central Sulawesi, Indonesia
}

Submitted 26 August 2021; Revised 7 September 2021; Accepted 27 September 2021; Published 29 October 2021 *Corresponding author: yuliet_susanto@yahoo.com

\begin{abstract}
Prolonged use of nonsteroidal anti-inflammatory drugs (NSAIDs) can trigger ulcers in the gastric mucosa. Pepolo stem bark (Bischofia javanica Blume) has been empirically used to treat gastric ulcers. This plant contains alkaloids, flavonoids, tannins, saponins, and triterpenoids with gastroprotective potential. This study aims to determine the gastroprotective effect of pepolo stem bark extract (PSBE) against gastric ulcers of Wistar rat induced by Aspirin. Aspirin $(150 \mathrm{mg} / \mathrm{kg} \mathrm{BW})$ was administered orally for eight days to all the groups except normal control. After $4 \mathrm{~h}$ of induction, normal and negative control received $\mathrm{Na} \mathrm{CMC} 0.5 \%$, while the positive group received Omeprazole $(3.6 \mathrm{mg} / \mathrm{kg} \mathrm{BW})$. The remaining low, middle, and high dose groups received PSBE (100, 200, and $300 \mathrm{mg} / \mathrm{kg} \mathrm{BW})$. On the $9^{\text {th }}$ day, the rats were dissected and tested on the stomach organs. The parameters were scored based on the severity of rat peptic ulcers, ulceration index, and percentage protection ratio. The scoring data were analyzed using the Kruskal-Wallis non-parametric test and post hoc the Mann-Whitney test. The administration of PSBE showed the ability to reduce the ulcer index and increase the percentage of ulcer inhibition significantly compared to the negative control $(\mathrm{p}<0.05)$, thus showed that PSBE could be a promising gastroprotective herbal medicine.
\end{abstract}

Keywords: Aspirin, gastric ulcer, pepolo stem bark

\section{Efek Gastroprotektif Ekstrak Kulit Batang Pepolo (Bischofia javanica Blume) Pada Tikus Galur Wistar Yang Diinduksi Aspirin}

\begin{abstract}
Abstrak
Penggunaan obat anti-inflamasi non-steroid (NSAID) untuk waktu yang lama dapat memicu ulkus dan perdarahan pada mukosa lambung. Kulit batang pepolo (Bischofia javanica Blume) telah digunakan secara empiris untuk pengobatan tukak lambung. Tanaman ini mengandung metabolit sekunder seperti alkaloid, flavonoid, tanin, saponin dan triterpenoid yang memiliki efek perlindungan terhadap lambung. Penelitian ini bertujuan untuk mengetahui efek gastroprotektif ekstrak kulit batang pepolo terhadap ulkus lambung tikus galur Wistar yang diinduksi aspirin. Aspirin $(150 \mathrm{mg} / \mathrm{kg} \mathrm{BB})$ diberikan secara oral selama delapan hari kepada semua kelompok kecuali kontrol normal. Sesudah 4 jam induksi, kontrol normal dan negatif diberikan suspensi $\mathrm{Na} \mathrm{CMC} 0,5 \%$ sedangkan kontrol positif diberikan omeprazole 3,6 mg/kg BB. Kelompok perlakuan lainnya diberikan ekstrak kulit batang pepolo (PSBE) dengan dosis rendah, sedang dan tinggi (100, 200 dan $300 \mathrm{mg} / \mathrm{kg} \mathrm{BB}$ ). Pada hari ke 9, tikus dibedah dan dilakukan pengujian pada organ lambung. Parameter yang diukur berdasarkan keparahan tukak lambung tikus, indeks ulserasi dan persentase rasio proteksi. Data hasil skoring dianalisis menggunakan uji non parametrik Krusskal Wallis dan uji lanjut Mann Whitney. Pemberian PSBE mampu menurunkan indeks ulser dan meningkatkan persentase inhibisi ulser yang berbeda signifikan $(\mathrm{p}<0,05)$ dibandingkan kelompok kontrol negatif. Penelitian ini menunjukkan bahwa PSBE dapat menjadi obat herbal gastroprotektif yang potensial.
\end{abstract}

Kata Kunci: Aspirin, kulit batang pepolo, dan tukak lambung. 


\section{Introduction}

Gastric ulcer is a digestive disorder that occurs when the inner layer of the stomach's skin is inflamed or swollen. ${ }^{1}$ Inflammation of the stomach can be caused by the gastric mucosa protection system which cannot protect the stomach due to continuous exposure to various harmful substances and exacerbate chronic inflammation and oxidative stress. ${ }^{2}$ Inflammation that damages the stomach and causes a cut or loss of part of the stomach wall can cause peptic ulcers. Ulcers occur if the wound has made a tear $\geq$ $5 \mathrm{~mm}$ in diameter ranging from submucosal to gastric wall mucosal muscles. Although the core mechanism is still being researched, it is thought that stomach ulcers are caused by an imbalance of protecting and destructive substances. ${ }^{3}$ Gastric ulcer disease is a disease that affects a vast number of people all over the world. Health profile data in Central Sulawesi 2020 shows gastritis is 2 of the ten most common diseases in Central Sulawesi, with a total of 100,525 cases. ${ }^{4}$ Risk factors for gastritis are nonsteroidal anti-inflammatory (NSAIDs), Helicobacter pylori infection, consuming alcohol, smoking, stress, irregular diet, and consuming too much spicy and acidic foods. ${ }^{5}$ Nonsteroidal anti-inflammatory drugs (NSAIDs) are a group of drugs widely used for rheumatoid arthritis, osteoarthritis, and relieve pain. This drug can cause damage to the gastric mucosa because of inhibition of enzyme COX-1 and gastroprotective prostaglandin, membrane permeabilization, and production of additional proinflammatory mediators. $^{6}$

Pepolo stem bark (Bischofia javanica Blume) is one of the plants used by the community as a traditional medicine to treat gastric ulcer disease. ${ }^{7}$ This plant was discovered to contain several significant phytochemical components and has been used in traditional medicine to treat various ailments.

Flavonoids and tannins have been identified as major secondary metabolites of Pepolo stem bark extract in phytochemical studies. ${ }^{8,9}$ Flavonoid compounds act as cytoprotectants (increased mucus), antioxidants, immunoregulators (decreased proinflammatory cytokines and increased anti-inflammatory cytokines), and antisecretory (decreased $\mathrm{H}+) .{ }^{10}$ The mechanism of gastroprotective action of tannins is based on their ability to promote tissue repair, their antioxidant activity, and their ability to interact with other molecules. This tannin-protein complex layer protects the stomach from chemical and mechanical injury or irritation in gastric ulcers. ${ }^{11}$ Based on the research library, there is no data available about gastroprotective activity in the stem bark extract of pepolo. Therefore researchers are interested in researching the gastroprotective effects of stem bark extract of pepolo in aspirin-induced male rats.

\section{Methods}

\subsection{Equipment}

The equipment used was Vacuum rotary evaporator (EYELA ${ }^{\circledR}$ N-1 200 B), analytical balance, oven (poL-HCD Aparathra), blenders (Sharp), glassware (Pyrex), reflux apparatus, heating mantle, analytic scales, hot plate, oral sonde, restrainer, rat cages, vernier caliper, and surgical scissors.

\subsection{Materials}

The materials used in this study were stem bark of pepolo (Bischofia javanica Blume), rat standard feed, ethanol $96 \%$ (Bratachem), cardio Aspirin ${ }^{\circledR} 100 \mathrm{mg}$, aquadest, $\mathrm{CMC} \mathrm{Na}$, Sodium Chloride $(\mathrm{NaCl})$, ketamine (Ketamine Hameln $\AA$ ), aqua pro injection, Dragendorff reagent, Liebermann Burchard reagent, Magnesium Powder, $\mathrm{FeCl}_{3}$ and Concentrated Hydrochloric Acid.

\subsection{Procedure}

\subsubsection{Animal Test}

The experiment was carried out on a total number of 24 healthy rats. The rats were aged between 2-4 months and weighed between 200-250 g. The study was approved by the Ethics Committee for Medical and Health Research, Faculty of Medicine, University of Tadulako (Number: 1436/UN 28.1.30/ $\mathrm{Kl} / 2021)$. Rats were housed individually in polypropylene cages, maintained under 
standard conditions (12 hrs light and 12 hrs dark cycle; $25^{\circ} \mathrm{C}$ and $45-55 \%$ relative humidity). They had been given standard pellet diet and water ad libitum throughout the study. The animals were adapted to the laboratory environment for seven days before being used in the study

\subsubsection{Preparation of Ethanol Extract}

The stem bark of pepolo is obtained in Sedoa Village, North Lore District, Poso Regency, Central Sulawesi. Stem bark was taken with chessboard technique, and then the bark was washed thoroughly and drained. The stem bark was cut into small pieces approximately $2.5 \times 3.5 \mathrm{~cm}$ to speed up drying. The samples were dried with the oven overnight at $50^{\circ} \mathrm{C}$. Once dry, simplicia was pollinated until smooth using a blender and sifted. Stored in tightly sealed plastic containers for use in research. A total of 1.1 $\mathrm{kg}$ of dried stem bark powder was extracted by reflux using $96 \%$ ethanol solvent of $6 \mathrm{~L}$. The powder was extracted for $3 \times 4$ hours at the boiling temperature of the solvent. The liquid extract obtained was collected, then evaporated with a vacuum rotary evaporator.

\subsubsection{Phytochemical Screening Procedures}

According to standard procedures, the ethanol extract was tested for secondary metabolites such as alkaloids, flavonoids, saponins, tannins, and steroids/triterpenoids. ${ }^{12}$

\subsubsection{Experimental Animals}

The experiment method followed Yasin, $\mathrm{H}$ et al. 2020 with minor changes. ${ }^{2}$ Stomach ulcer was induced by Aspirin $150 \mathrm{mg} / \mathrm{kg} \mathrm{BW}$. Omeprazole $3.6 \mathrm{mg} / \mathrm{kg}$ BW has been utilized as a standard antiulcer medicine since it is an irreversible and selective proton pump inhibitor. Rats were distributed randomly into six groups (4 rats each). Treatment was as follow:

Group I: normal control, the rats were given orally suspensions $0.5 \% \mathrm{CMC} \mathrm{Na}$

Group II: negative control, administered aspirin suspension orally. After 4 hours, the rat was given orally suspensions $0.5 \% \mathrm{CMC}$ $\mathrm{Na}$.
Group III: positive control, administered aspirin suspension orally. After 4 hours, the rat was given omeprazole suspension orally.

Group IV, V, and VI: test group dose, administered aspirin suspension orally. After 4 hours, the rat was given orally suspended pepolo stem bark extract at a dose of $100 \mathrm{mg}$, 200 , and $300 \mathrm{mg} / \mathrm{kg} \mathrm{BW}$, respectively.

Treatment was given for eight days. Then on the 9th day, termination was carried out on test animals that had previously been fasted for 12 hours. Then after the animals were sacrificed, stomachs were detached, and the gastric ulcer lesions were measured.

\subsubsection{Macroscopic Observations}

On the ninth day, the rat was dissected and taken from his stomach organs. The gastric organs are opened along a minor curve, washed with $\mathrm{NaCl} 0.9 \%$, and then stretched to facilitate lesion length measurement. Measurement of ulcer/ulcer severity score was performed by examining the stomach's inner surface and measuring lesions formed using a vernier caliper.

Lesions were scored based on the length of the lesion in order to be analyzed. The score given is as follows: normal stomach $=1 ;$ reddish $/$ red stomach $=1.5 ;$ bleeding spots or ulcers diameter up to $0.5 \mathrm{~mm}=2$; hatchlings with a diameter/ length of 0.5-1.5 $\mathrm{mm}=3$; hatchlings with a diameter / length of 1.6-4 $\mathrm{mm}=4$; ulcers with a diameter of $>4 \mathrm{~mm}=5$; perforation with a diameter of 2-7 $\mathrm{mm}=6$; perforation with a diameter of 8-13 $\mathrm{mm}=7$; perforation with a diameter of $>13 \mathrm{~mm}=8$. According to Adefisayo, M.A, 2018, the number of ulcers that occur and the severity of ulcers is determined by the ulcer index formula: ${ }^{13}$

Ulcer Index $(\mathrm{UI})=($ total ulcer score $) /$ (number of animals that have ulceration)

While the level of healing is assessed based on the percentage of ulcer inhibition:

$\%$ inhibition of ulcers $=100 \%-[(\mathrm{IU}$ treatment group)/(IU group NC) x 100\%]

\subsubsection{Data Analysis}

Data research was analyzed using SPSS software 26. Kruskal-Wallis nonparametric 
test was used to analyze data and then continued with post hoc Mann-Whitney's analysis. The significant value in this study was $p<0.05$ ( $95 \%$ of confidence level).

\section{Results}

3.1. Extraction and phytochemical screening of pepolo stem bark extracts

This study used the reflux method. A total of $1.1 \mathrm{~kg}$ of simplicia powder was obtained, $24.51 \mathrm{~g}$ of extract with the percentage of $2.2 \%$, and the extracted color is blackish-red. The preliminary phytochemical screening was performed on ethanol extracts of pepolo the results indicated several important phytochemicals natural product groups. The change of colours or the precipitate formation was observed when the test reagent was added to the prepared sample for the phytochemical test. The identification results showed the presence of alkaloids, flavonoids, saponins, tannins, and triterpenoids.

\subsection{Gastroprotective effect}

Macroscopic to the gastric mucosa was performed by giving a score based on the severity of peptic ulcers that have been predetermined. The score data obtained was then used to calculate the ulcer index. The ulcer index was calculated by comparing the total number of scores with the number of rats that experienced ulceration. The results of assessment of damage to the gastric mucosa can be seen in Table 1.

The cure rate is assessed based on the percentage of ulcer inhibition. The percentage of ulcer inhibitions for each test group can be seen in Figure 1 and the macroscopic image of the rat stomach obtained can be seen in Figure 2 below.

\section{Discussions}

The sample used in this study was pepolo stem bark extract (Bischofia javanica Blume). Ethanol extract was obtained using the reflux method. This method was chosen because the sample used is the bark of the pepolo, which has a hard texture and is resistant to heat. ${ }^{14}$ The resulting stem bark extract of pepolo was tested through phytochemical screening to identify its compounds. The results showed that pepolo stem bark extract contains flavonoid compounds, saponins, alkaloids, triterpenoids, and tannins. These results are following previous research that ethanol extract of pepolo stem bark contains tannins and flavonoid compounds that have antioxidant activity. ${ }^{15}$ Therefore, based on the description, research has been conducted on gastroprotective tests on aspirin-induced male rats, knowing whether or not the extract affects the stomach of rats and knowing the dose that can give a healing effect on ulceration in rat stomach.

The comparison or positive control used in this study was Omeprazole. It was used to see the influence on the stomach that has proven efficacy in protecting gastric mucosa. Positive controls are also used to prove that the method used is valid. Proton pump inhibitors are used to treat gastric acid hypersecretion that occurs in gastric and duodenal ulcers and

Table 1. Effect of extract stem bark of pepolo on morphological damage score and ulcer index of gastric tissue

\begin{tabular}{lcc}
\hline \multicolumn{1}{c}{ Group } & Average score & Ulcer Index \\
\hline Normal control & $0.00 \pm 0.00^{\mathrm{a}}$ & 0 \\
Negative control (Aspirin) & $5.75 \pm 0.96^{\mathrm{c}}$ & 5.75 \\
Positive control (Omeprazole) & $0.00 \pm 0.00^{\mathrm{a}}$ & 0 \\
Stem bark extract $100 \mathrm{mg} / \mathrm{kg} \mathrm{BW}$ & $3.25 \pm 2.22^{\mathrm{b}}$ & 4.33 \\
Stem bark extract $200 \mathrm{mg} / \mathrm{kg} \mathrm{BW}$ & $0.00 \pm 0.00^{\mathrm{a}}$ & 0 \\
Stem bark extract $300 \mathrm{mg} / \mathrm{kg} \mathrm{BW}$ & $0.00 \pm 0.00^{\mathrm{a}}$ & 0 \\
\hline Note: & \\
Values in the same column with different letters are a significant difference $(\mathrm{p}<0.05)$
\end{tabular}




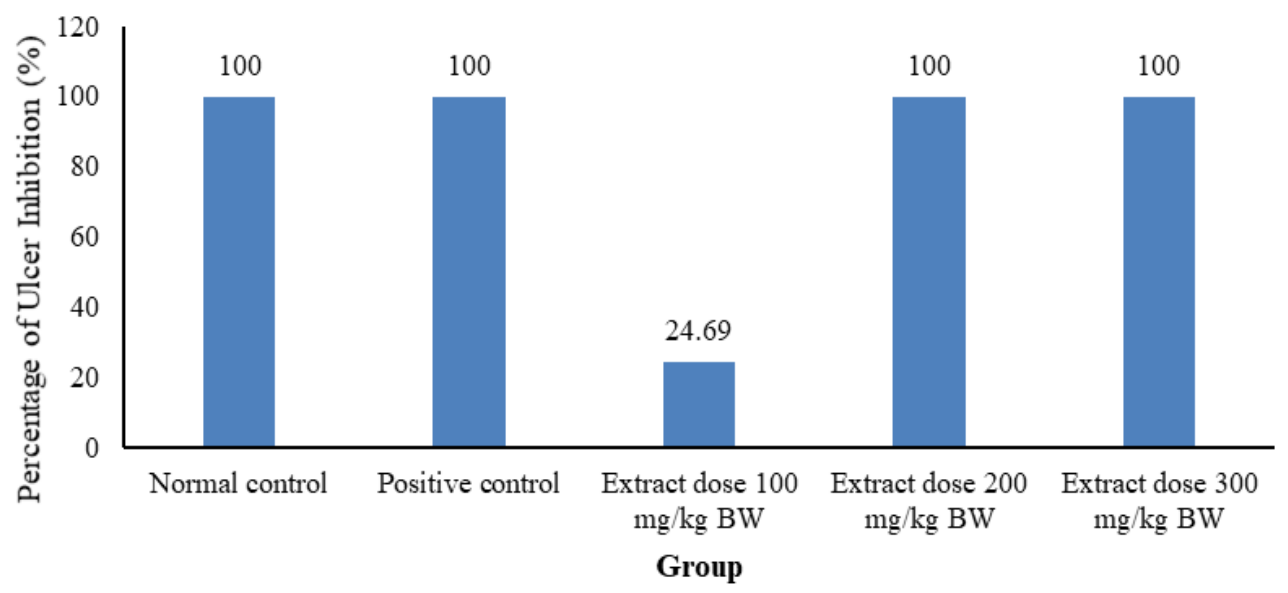

Figure 1. Percentage graph of ulcer inhibition

is used in therapy to radicalize Helicobacter pylori in combination with antibiotics. Omeprazole is the first member drug to bind to the $\mathrm{K}+\mathrm{H}+$-ATPase system of parietal cells (proton pumps) to inhibit the secretion of hydrogen ions into the gastric cavity. Proton pump inhibitors (PPI) were chosen as a positive control because they can effectively reduce ulcers in patients taking Aspirin or other NSAID. ${ }^{16}$ Although NSAID treatment was still used, treatment with proton pump inhibitors with administration once a day can trigger ulcer healing. ${ }^{17}$

The higher the ulcer index value indicates that the greater the gastric damage experienced, and the higher the percentage of ulcer inhibition indicates that the greater the ability to heal and reduce the rate of gastric damage. Based on the results of the calculation (Table 1 and Figure 1), it is known that the ulcer index of the negative control group, normal control, positive control, ethanol extract of pepolo stem bark at doses of 100,200 , and $300 \mathrm{mg} / \mathrm{kg} \mathrm{BW}$ respectively is $5.75 ; 0 ; 0 ; 3.25 ; 0$ and 0 . Until the healing rate is obtained based on the percentage of ulcer inhibition/ulcer by $0 \%$ for the negative control, $100 \%$ for the normal control group, positive control and ethanol extract at a dose of $200 \mathrm{mg} / \mathrm{kg} \mathrm{BW}$ and $300 \mathrm{mg} / \mathrm{kg} \mathrm{BW}$ while for ethanol extract dose $100 \mathrm{mg} / \mathrm{kg} \mathrm{BW}$ the healing rate is $24.69 \%$ respectively. The value of this healing rate was increasing with the increase of the dose given. Based on Table 1, it can be concluded that the entire treatment group of ethanolic extract of pepolo stem bark showed a decrease in the ulcer index's mean value of the rat's stomach compared to the negative control. These results indicate that pepolo stem bark extract affects the healing of peptic ulcers. The positive control group (Omeprazole) had a significant $(\mathrm{p}<0.05)$ lower ulcer score compared to the negative control group. It proves that the methods and workings used in this study were correct. Likewise, there are significant differences $(\mathrm{p}<0.05)$ between normal control groups and negative controls. This can be explained because the normal group did not get induced nor treated by anything so that the stomach state was physically not ulcerated, while the negative control group (Na CMC) get induced by Aspirin without getting treated, so the stomach has ulcers.

The evaluation of gastric lesions measurement parameters was done with vernier caliper assistance. Figure 2 shows the macroscopic description of lesions in the gastric organs in each treatment group. The normal group (1a) does not indicate lesions of the stomach. The negative control (1b) indicates many lesions in the stomach, the larger size of the lesions, and tend to the perforation of the stomach organs. Meanwhile, the preventive effect on ulceration number and severity of ulcers was seen in rats given pepolo stem bark extract. Gastric observations showed that rats that had 


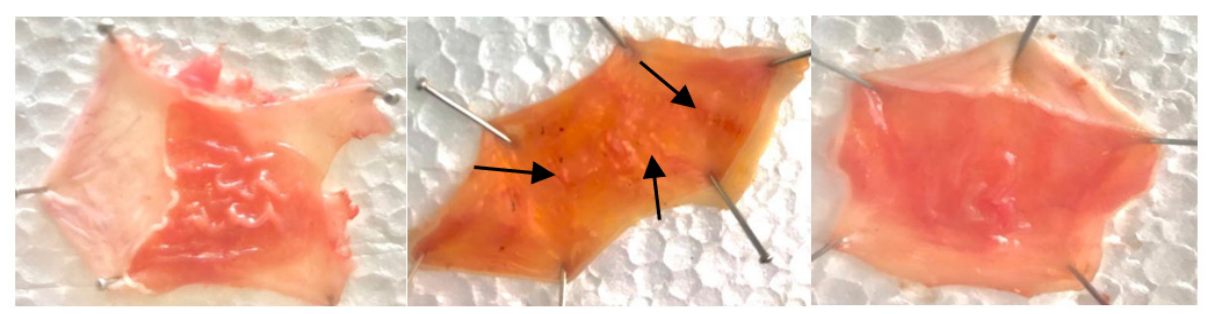

(a)

(b)

(c)

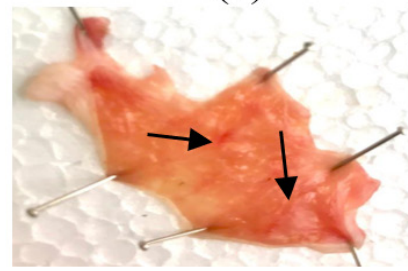

(d)

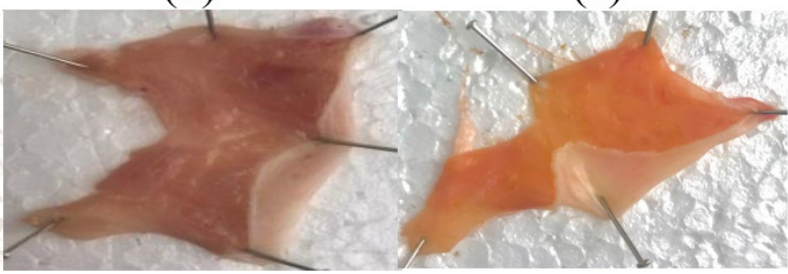

(f)

Figure 2. Macroscopic view of ulcer areas stomach tissues of experimental groups: (a) normal control (b) negative control (aspirin $150 \mathrm{mg} / \mathrm{kg} \mathrm{BW}$ ), (c) positive control (omeprazole $3.6 \mathrm{mg} / \mathrm{kg} \mathrm{BW}$ ), (d) pepolo stem bark extract $100 \mathrm{mg} / \mathrm{kg} \mathrm{BW}$, (e) pepolo stem bark extract $200 \mathrm{mg} / \mathrm{kg} \mathrm{BW}$, (f) pepolo stem bark extract $300 \mathrm{mg} / \mathrm{kg} \mathrm{BW}$, and $(\longrightarrow$ ) Black arrows point to the hemorrhagic bands.

received $100 \mathrm{mg} / \mathrm{kg} \mathrm{BW}$ of pepolo stem bark extract could reduce the formation of ulcers. Pepolo stem bark extract at 200 and $300 \mathrm{mg} /$ $\mathrm{kg} \mathrm{BW}$ has preventive effectiveness against ulcer with no significant difference compared to normal control.

The statistical analysis results showed that the severity of ulcers in the pepolo stem bark extract group with a dose of $100 \mathrm{mg} /$ $\mathrm{kg} \mathrm{BW}$ against a dose of 200 and $300 \mathrm{mg} / \mathrm{kg}$ BW showed a significant difference $(\mathrm{p}<0.05)$. Meanwhile, the dose of $200 \mathrm{mg} / \mathrm{kg} \mathrm{BW}$ to $300 \mathrm{mg} / \mathrm{kg}$ BW did not show a significant difference $(p<0.05)$. Based on Figure 1 can be seen percent the rate of healing ulcers per treatment. Percent ulcer healing rate was used to determine how much the test compound's ability to reduce the severity of peptic ulcers in rats compared to the negative control $(\mathrm{Na}$ CMC 0.5\%). The results obtained, stem bark extract of pepolo dose 100, 200, and $300 \mathrm{mg} /$ $\mathrm{kg} \mathrm{BW}$, show the ability and activity as a gastroprotective with the optimal dose of 200 $\mathrm{mg} / \mathrm{kg} \mathrm{BW}$.

The gastroprotective effect was thought due to secondary metabolites in the pepolo stem bark extract according to the results of phytochemical screening, namely alkaloids, flavonoids, saponins, tannins, and triterpenoids.

Alkaloids work with a mechanism to reduce gastric acid secretion, increase mucus and alkaline secretions, and increase gastric mucosal blood flow to aid in the healing and prevention of gastric ulcers against irritant agents/factors. ${ }^{18}$ Flavonoids work by protecting the gastric mucosa against ulcerogenic agents through mechanisms of free radical destruction, increased mucus production, and antisecretory system. ${ }^{19}$ Tannins compounds are also known to have gastroprotective effects that inhibit gastric secretion and local gastric mucosal protection. Saponins are probably due to the presence of antioxidant activity. $^{20}$ Triterpenoids potent gastroprotective and curative effects were probably due to their antioxidant, antisecretory, increased gastric mucus production, and induced PGE2 levels. ${ }^{21}$

\section{Conclusions}

This study provides the rationale for using pepolo stem bark to develop a new drug for the treatment and prevent peptic ulcer 
disease. This study establishes that pepolo stem bark extract has the gastroprotective ability by decreasing the ulcers index and increasing the ratio of protection at an optimal dose was $200 \mathrm{mg} / \mathrm{kg}$ BW. Advanced research is required to highlight the fundamental mechanism of the gastroprotective potential of pepolo stem bark.

\section{Acknowledgments}

The authors are highly thankful to the Pharmacology-Clinical Pharmacy Laboratory, Department of Pharmacy, University of Tadulako, for providing the facilities and specialties for this research work

\section{Daftar Pustaka}

1. Jiin WH, Hidayat EM, Lukman K. Gastroprotective Effect of Carrot (Daucus carota L.) Juice in Rat Models. Althea Med J. 2014;1(1):35-9.

2. Yasin H, Tariq F, Sameen A, Ahmad $\mathrm{N}$, Manzoor MF, Yasin $\mathrm{M}$, et al. Ethanolic extract of okra has a potential gastroprotective effect on acute gastric lesions in Sprague Dawley rats. Food Sci Nutr. 2020;8(12):6691-8.

3. Trinovita E, Fatmaria F. Evaluation of Gastroprotective Activity of Cemot Leaves (Passiflora foetida L.) Extracted by Ultrasonic Assisted Extraction (UAE) Against Ethanol-Induced Gastric Lesions in Rats. Maj Obat Tradis. 2020;25(2):108.

4. Dinas Kesehatan Provinsi Sulawesi Tengah. Profil Kesehatan Provinsi Sulawesi Tengah Tahun 2020. 2020.

5. Di Saverio S, Bassi M, Smerieri N, Masetti M, Ferrara F, Fabbri C, et al. Diagnosis and treatment of perforated or bleeding peptic ulcers: 2013 WSES position paper. World J Emerg Surg. 2014;9(45):1-15.

6. Sinha M, Gautam L, Shukla PK, Kaur P, Sharma S, Singh TP. Current perspectives in NSAID-induced gastropathy. Mediators Inflamm. 2013;2013:1-11.

7. Purba EC, Silalahi M, Nisyawati. Gastronomic ethnobiology of "terites"-a traditional Batak Karo medicinal food: A ruminant's stomach content as a human food resource. J Ethn Foods [Internet].
2018;5(2):114-20. Available from: https:// doi.org/10.1016/j.jef.2018.06.002

8. Pangodian A, Nainggolan M, Dalimunthe A. Characterization and AntiInflammatory Activity of Ethanol Extract of Sikkam (Bischofia javanica Blume) Stem Bark. Asian J Pharm Res Dev. 2020;8(4):16-20.

9. Blume B, Rajbongshi P, Zaman K, Boruah S, Das S. A Review on Traditional Use and Phytopharmacological Potential of Bischofia javanica Blume. 2014;24(2):249.

10. Serafim C, Araruna ME, Júnior EA, Diniz M, Hiruma-Lima C, Batista L. A Review of the Role of Flavonoids in Peptic Ulcer (2010-2020). Molecules. 2020;25(22):132.

11. Demarque DP, Callejon DR, Oliveira GG De, Silva DB, Carollo CA, Lopes NP. The role of tannins as antiulcer agents : a fluorescence-imaging based study. Rev Bras Farmacogn [Internet]. 2018;28(4):425-32. Available from: https://doi.org/10.1016/j.bjp.2018.03.011

12. Tiwari P, Kumar B, Kaur M, Kaur G, Kaur H. Phytochemical screening and Extraction: A Review. Int Pharm Sci. 2011;1(1):98-106.

13. Adefisayo MA, Akomolafe RO, Akinsomisoye OS, Alabi QK, Ogundipe $\mathrm{L}$, Omole JG, et al. Protective effects of methanol extract of Vernonia amygdalina (Del.) leaf on aspirin-induced gastric ulceration and oxidative mucosal damage in a rat model of gastric injury. DoseResponse. 2018;16(3):1-11.

14. Najid A, Elya B, Noviani A. Arginase Inhibitory Activity of Stem Bark Extracts of Caesalpinia tortuosa ROXB. Int J Alpplied Pharm. 2018;10(1):130-2.

15. Itoh T, Xia J, Magavi R, Nishihata T, Manurung DP, Sundaryono A, Amir H. Penentuan Potensi Ekstak Kulit Batang Tumbuhan Sikkam (Bischofia javanica Blume) Sebagai Antioksidan Dengan Metode DPPH dan Sitotoksik Dengan Metode BSLT. Alotrop, J Pendidikan dan Ilmu Kimia [Internet]. 2020;4(1):83-91. Available from: https://ejournal.unib. 
ac.id/index.php/alotropjurnal/article/ download/13715/6768

16. Robinson M, Horn J. Clinical Pharmacology of Proton Pump Inhibitors What the Practising Physician Needs to Know. Drugs. 2003;63(24):2739-54.

17. Goh V. Coprescribing proton-pump inhibitors with nonsteroidal antiinflammatory drugs : risks versus benefits. J Pain Res. 2018;361-74.

18. Falcão HDS, Leite JA, Barbosa-Filho JM, De Athayde-Filho PF, Chaves MCDO, Moura MD, et al. Gastric and duodenal antiulcer activity of alkaloids: A review. Molecules. 2008;13(12):3198-223.
19. Zhang W, Lian Y, Li Q, Sun L, Chen R, Lai X, et al. Preventative and therapeutic potential of flavonoids in peptic ulcers. Molecules. 2020;25(20):1-31.

20. de Jesus NZT, de Souza Falcão H, Gomes IF, de Almeida Leite TJ, de Morais Lima GR, Barbosa-Filho JM, et al. Tannins, peptic ulcers and related mechanisms. Int J Mol Sci. 2012;13(3):3203-28.

21. Netala VR, Ghosh SB, Bobbu P, Anitha D, Tartte V. Triterpenoid saponins: A review on biosynthesis, Applications and mechanism of their action. Int J Pharm Pharm Sci. 2015;7(1):24-8. 